\title{
Association of Hyperuricaemia and Gout with Hyperparathyroidism
}

\author{
J. T. SCOTT,* M.B., M.R.C.P. ; A. ST. J. DIXON,*† M.D., M.R.C.P. \\ E. G. L. BYWATERS,* M.B., F.R.C.P.
}

Brit. med. F., 1964, 1, 1070-1073

The occurrence of gout in patients with hyperparathyroidism has been noted in the past two years, but prior examples exist. The patient of Downs and Scott (1941) with a parathyroid adenoma, nephrocalcinosis, and renal failure also had gout, as did the patient of Hosking and Clennar (1960) with a parathyroid adenoma, articular cartilage calcification, and renal calculi. Gordan et al. (1962), reviewing various clinical relationships in 104 patients with hyperparathyroidism, found gout in two, the association being regarded as probably fortuitous. Dent (1962) noted acute gout in three out of 80 cases, with no suggestion of anything more than a coincidental relationship. Mintz et al. (1961), however, studying eight patients with hyperparathyroidism, found a raised serum uric acid in no fewer than four, one of them with a history of gout.

In a recent review of joint lesions in 19 cases of hyperparathyroidism (Bywaters et al., 1963), 18 of them primary and due to an adenoma, it was found that of the 12 in which the serum uric acid was measured hyperuricaemia was present in 11, of which five had clinical gout. The present paper gives an account of these cases.

All except one of the 12 patients were treated at Hammersmith, where serum-uric-acid levels were estimated by the method of Caraway (1955) adapted for use on an autoanalyser. The upper limit of normal with this method is $6 \mathrm{mg} . / 100 \mathrm{ml}$. for males and post-menopausal women, and $5 \mathrm{mg}$. $/ 100 \mathrm{ml}$. for premenopausal women. $\ddagger$ Case 11 was studied at Taplow, using the method of Bidmead (1951).

The 12 patients studied are summarized in the Table. Apart from Case 12, with a normal serum uric acid, they may be considered in certain different categories.

\begin{tabular}{|c|c|c|c|c|c|c|c|c|}
\hline \multicolumn{9}{|c|}{ Summary of the 12 Cases } \\
\hline $\begin{array}{l}\text { Case } \\
\text { No. }\end{array}$ & Sex & $\begin{array}{l}\text { Admis- } \\
\text { sion } \\
\text { Age }\end{array}$ & \begin{tabular}{|c} 
Pre-op. \\
Blood \\
Urea \\
(mg.l \\
100 ml.)
\end{tabular} & $\begin{array}{l}\text { Pre-op. } \\
\text { Serum } \\
\text { Calcium } \\
\text { (mEq/1.) }\end{array}$ & $\begin{array}{c}\text { Max. } \\
\text { S.U.A. } \\
\text { (mg.l } \\
100 \mathrm{ml} .)\end{array}$ & $\begin{array}{c}\text { Clinical } \\
\text { Gout }\end{array}$ & $\begin{array}{l}\text { Radiol- } \\
\text { ogical } \\
\text { Nephro- } \\
\text { Calcino- } \\
\text { sis }\end{array}$ & $\begin{array}{l}\text { Other } \\
\text { Suft-tissue } \\
\text { Calcifica- } \\
\text { tion }\end{array}$ \\
\hline \begin{tabular}{r|}
1 \\
2 \\
3 \\
4 \\
$5 *$ \\
6 \\
7 \\
8 \\
9 \\
10 \\
11 \\
12
\end{tabular} & $\begin{array}{c}\mathbf{F} \\
\mathbf{F} \\
\mathbf{M} \\
\mathbf{F} \\
\mathbf{M} \\
\mathbf{F} \\
\mathbf{F} \\
\mathbf{F} \\
\mathbf{F} \\
\mathbf{F} \\
\mathbf{F}\end{array}$ & $\begin{array}{l}26 \\
40 \\
33 \\
61 \\
41 \\
32 \\
57 \\
66 \\
72 \\
73 \\
60 \\
57\end{array}$ & $\begin{array}{r}27 \\
53 \\
74 \\
75 \\
170 \\
41 \\
62 \\
85 \\
72 \\
120 \\
70 \\
17\end{array}$ & $\begin{array}{l}7.8 \\
7.0 \\
6.9 \\
8.4 \\
3.4 \\
7.0 \\
7.7 \\
6.7 \\
8.5 \\
5.2 \\
6.2 \\
6.6\end{array}$ & $\begin{array}{r}10.8 \\
9.4 \\
16.2 \\
11.3 \\
12.0 \\
7.4 \\
14.2 \\
6.6 \\
6.7 \\
8.3 \\
12.7 \\
3.8\end{array}$ & $\begin{array}{l}+ \\
+ \\
+ \\
+ \\
+ \\
0 \\
0 \\
0 \\
0 \\
0 \\
0 \\
0\end{array}$ & $\begin{array}{c}+ \\
+ \\
0 \\
+ \\
0 \\
+ \\
+ \\
0 \\
0 \\
0 \\
+ \\
0\end{array}$ & $\begin{array}{c}0 \\
0 \\
0 \\
+ \\
0 \\
+ \\
+ \\
0 \\
+ \\
+ \\
0 \\
0\end{array}$ \\
\hline
\end{tabular}

With Gout.-(1) Gout preceding removal of parathyroid adenoma with no evident impairment of renal function (Case 1). (2) Gout preceding removal of parathyroid adenoma with some impairment of renal function (Case 2). (3) Gout following parathyroidectomy and occurring during renal insufficiency (Cases 3 and 4). (4) Gout occurring in the course of secondary (renal) hyperparathyroidism and renal insufficiency (Case 5).

* From the Department of Medicine, Postgraduate Medical School of London, and the Canadian Red Cross Memorial Hospital, Taplow. + Now at St. Stephen's Hospital, London S.W.10.

$¥$ These values were obtained by duplicate estimation in our laboratory and in that of the Rheumatism Research Centre, the Royal Infirmary, Manchester, of sera from the population survey of Popert and Hewitt (1962), kindly supplied by Miss J. Venise Hewitt.
With Hyperuricaemia but Without Gout.-(5) Hyperparathyroidism and hyperuricaemia with no evident renal impairment (Case 6). (6) Hyperparathyroidism, hyperuricaemia, and renal insufficiency (Cases 7-11). None of these patients gave a family history of gout.

\section{Case 1}

In this case an attack of gout occurred shortly before removal of a parathyroid adenoma, renal function as assessed by bloodurea levels being normal throughout.

A woman aged 26 was referred to the orthopaedic clinic at Hammersmith Hospital in December 1960 with an 18-months history of low back pain, loss of energy, and excessive thirst. Physical examination was negative, the blood-pressure being 125/70 $\mathrm{mm}$. Hg. Radiographs showed no abnormality of the vertebrae, but revealed the presence of nephrocalcinosis and cortical erosions in the phalanges of the hands. Serum calcium $8.0 \mathrm{mEq} / 1$, phosphate $1.5 \mathrm{mEq} / 1$., alkaline phosphatase $11 \mathrm{King}$-Armstrong units, blood urea $27 \mathrm{mg} . / 100 \mathrm{ml}$. Serum-uric-acid levels ranged from 6.8 to $10.8 \mathrm{mg} . / 100 \mathrm{ml}$.

On 24 February 1961, while an in-patient awaiting exploration of the parathyroid glands, she developed sudden severe pain in both knees, which were red and hot. Colchicine by mouth produced relief of pain after four hours. Uric-acid-clearance figures (twohour periods) that day and the next were 13.2 and $8.1 \mathrm{ml} . /$ minute, the serum levels being 5.7 and $6.1 \mathrm{mg}$.

On 28 February a histologically confirmed parathyroid adenoma was removed by Professor Aird. The serum calcium fell to normal

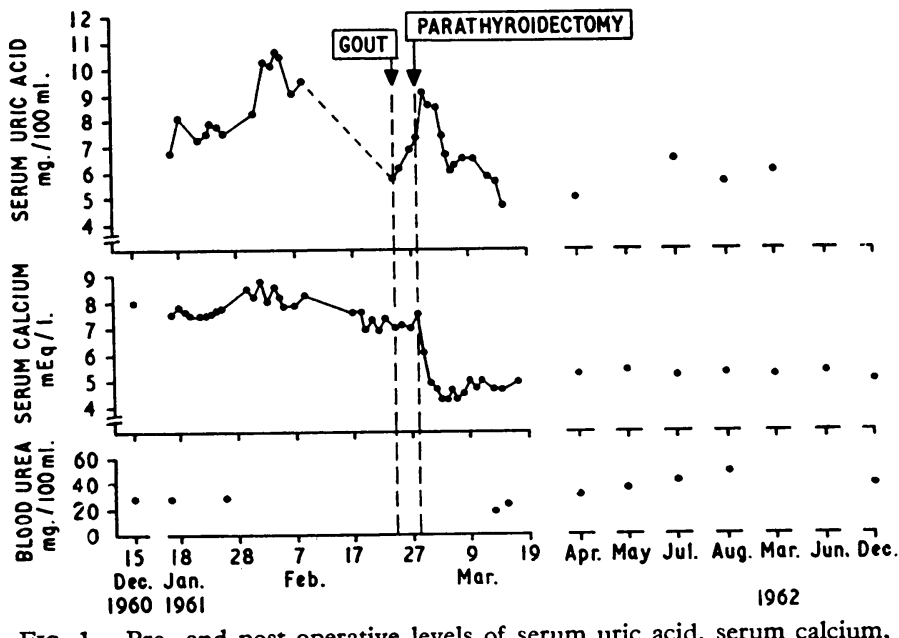

FIG. 1.-Pre- and post-operative levels of serum uric acid, serum calcium, and blood urea in Case 1 .

levels within two days, lying then between 4.2 and $5.1 \mathrm{mEq} / 1$. Serum uric acid rose from $7.2 \mathrm{mg}$. on 28 February to $9.1 \mathrm{mg}$. on $1 \mathrm{March}$, falling to $6 \mathrm{mg}$. by 6 March. Blood urea was not estimated during this period, but on 13 March it remained at the normal level of $16 \mathrm{mg}$. (Fig. 1).

The patient has been well since the operation, serum-calcium levels lying between 5 and $5.6 \mathrm{mEq} / 1$., and serum uric acid between 4.7 and $6.3 \mathrm{mg} . / 100 \mathrm{ml}$. There have been no further attacks of gout. 


\section{Case 2}

In this case the first attack of premenopausal gout occurred six years before the diagnosis of hyperparathyroidism with nephrocalcinosis.

The patient was well until 1950, when at the age of 30 she had a haematemesis from a radiologically confirmed duodenal ulcer. The first attack of gout was in 1954 in the first metatarsophalangeal joint, and attacks occurred annually for three years, then more frequently. In 1957 the serum uric acid was 8.5 mg./100 ml.

In 1960, when aged 40, she was referred to Hammersmith Hospital because of epigastric discomfort. She admitted to nocturia three or four times each night but was otherwise well. Physical examination was negative but there was proteinuria; nephrocalcinosis was seen on radiography, which also showed a gouty erosion in the right great toe and generalized loss of bone density with no evidence of hyperparathyroidism. Barium-meal examination showed a duodenal ulcer. Serum calcium was raised at $7 \mathrm{mEq} / 1$, phosphate $2.7 \mathrm{mEq} / 1$., alkaline phosphatase $10 \mathrm{~K}$.-A. units. Blood urea was 35 , 44, and $53 \mathrm{mg} . / 100 \mathrm{ml}$. on three occasions, and impairment of renal function was confirmed by a urea clearance of $37 \%$ of normal and phenolsulphonphthalein excretion of $25 \%$ in one hour. Serum uric acid lay between 7.7 and $9.5 \mathrm{mg} . / 100 \mathrm{ml}$.

During a period of observation the patient was given pyrazinamide by mouth, $2.5 \mathrm{~g}$. daily for three days, producing a sharp rise in serum uric acid to $11.8 \mathrm{mg}$. with a corresponding fall in clearance (Fig. 2). Probenecid in a dose of $2 \mathrm{~g}$. daily for three days then

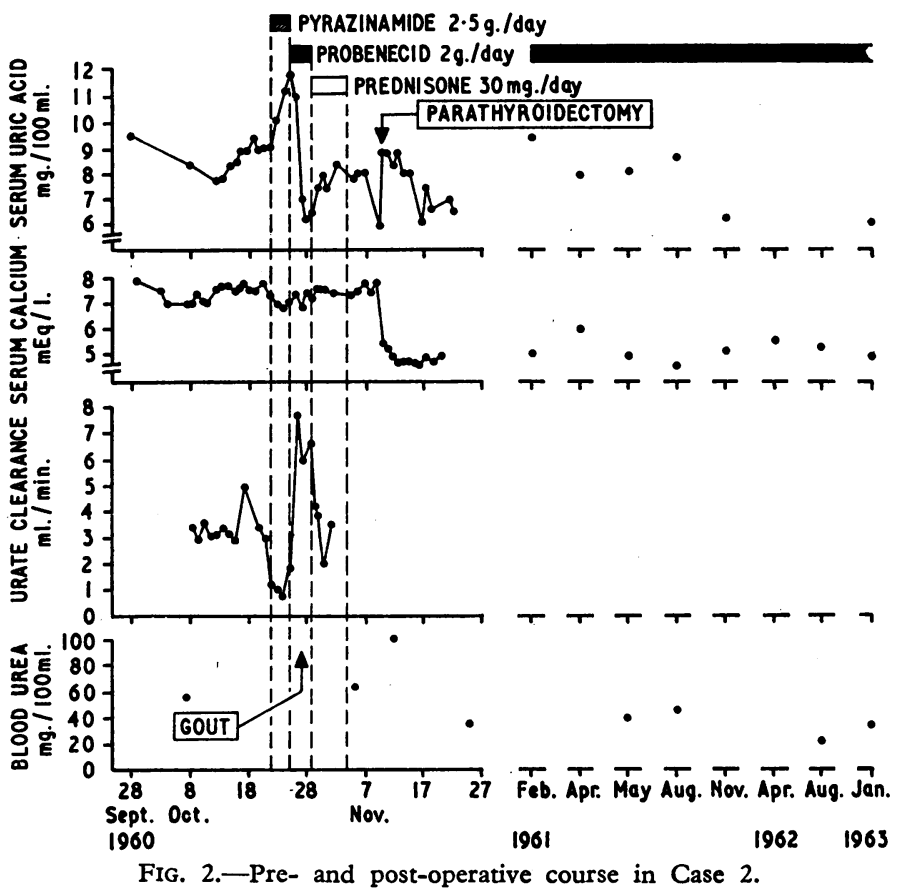

caused a fall in serum uric acid to $6.5 \mathrm{mg}$. There was little change in uric-acid excretion during a subsequent period of six days on prednisone $30 \mathrm{mg}$. daily. On the first day on probenecid there was an acute attack of gout.

On 10 November 1960 a paratyphoid adenoma was removed (Professor Aird). The post-operative course was satisfactory, serum calcium falling from $7.6 \mathrm{mEq} / \mathrm{l}$. immediately pre-operatively to $4.7 \mathrm{mEq} / \mathrm{l}$. by four days after the operation. Blood urea was 100 $\mathrm{mg} . / 100 \mathrm{ml}$. two days post-operatively, but fell to $33 \mathrm{mg}$. by 26 November. Serum uric acid was $8.8 \mathrm{mg}$. immediately preoperatively; there was no post-operative rise parallel with the rise in blood urea, and the level fell gradually to $6.2 \mathrm{mg}$. after a few days. At follow-up in February 1961, however, the serum uric acid was $9.4 \mathrm{mg}$., and treatment with probenecid, $2 \mathrm{~g}$. daily, was started. At later visits serum uric acid was between 6 and $8.6 \mathrm{mg}$. It is uncertain how regularly she was taking probenecid; she continued to have occasional attacks of gout, relieved by colchicine, but was otherwise well.

\section{Cases 3 and 4}

In Cases 3 and 4 we have no information about serum-uricacid levels before removal of a parathyroid adenoma. In both cases there was evidence of impaired renal function preoperatively, as shown by a raised blood urea. Case 4 had radiological nephrocalcinosis, but this was not seen in Case 3. In both patients there was a temporary rise of blood urea after the operation and both developed acute gout for the first time during this phase-13 days post-operatively in Case 3 and 40 days post-operatively in Case 4.

\section{Case 4}

The patient had symptoms of slight hemiparesis in 1955 at the age of 58 and was told her blood-pressure was raised. In 1956 an intravenous pyelogram, carried out because of recurrent pyelitis, showed a right hydronephrosis and calculus. During the next two years she complained of pain and stiffness in the knees and back and nocturnal frequency of micturition. When seen at Hammersmith in 1958 she was noted to have a gross kyphosis with degenerative arthritis in the knees. There was corneal calcification and the blood-pressure was $220 / 110$. Serum calcium was $8.4 \mathrm{mEq} / 1$., phosphate $2.5 \mathrm{mEq} / 1$., alkaline phosphatase $74 \mathrm{~K}$.-A. units, blood urea $75 \mathrm{mg}$. Maximum urine concentration after "pitressin" was 1012. $X$-ray examination showed changes of hyperparathyroidism in the fingers and skull, with erosions in the femoral and tibial condyles and patellae. The spine had a " rugger jersey" appearance and bilateral nephrocalcinosis was seen. Iliac-crest-bone biopsy confirmed the diagnosis of osteitis fibrosa, and on 1 August 1958 a parathyroid adenoma was removed by Mr. Selwyn Taylor. There was a sharp fall in serum calcium to $4 \mathrm{mEq} / 1$. with post-operative tetany (Fig. 3), but the immediate post-operative course was otherwise uncomplicated. There was a slight rise in blood urea to 96 $\mathrm{mg} . / 100 \mathrm{ml}$., falling again to $76 \mathrm{mg}$. by 8 August.

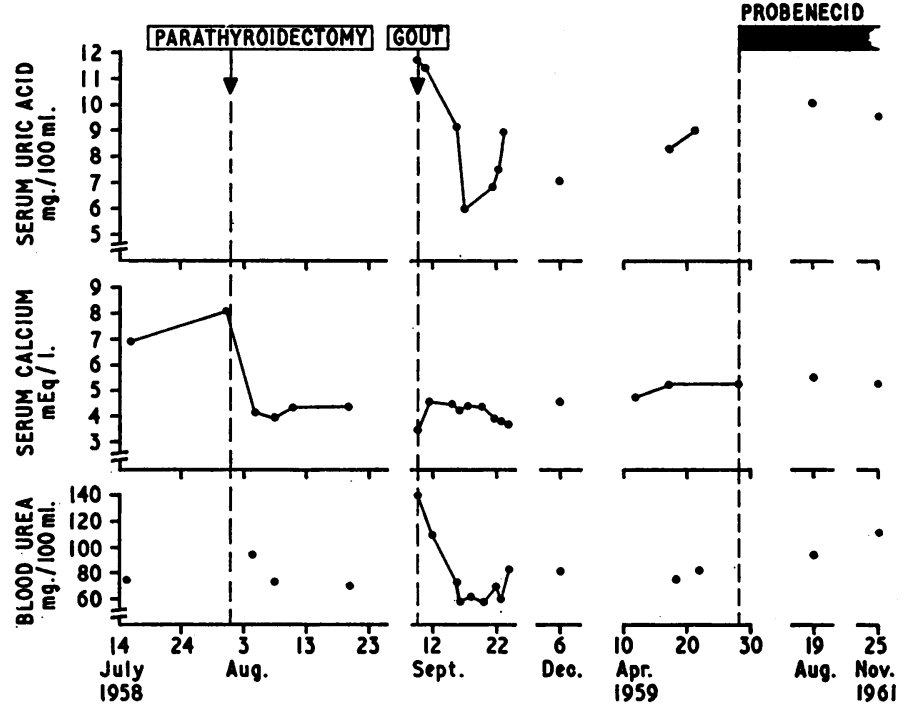

FIG. 3.-Pre- and post-operative course in Case 4.

The patient was discharged on 20 August. On 10 September, however, she was readmitted with acute gout, the right great toe being red and extremely tender. The jugular venous pressure was raised to $4 \mathrm{~cm}$. and there was pitting oedema of the sacrum and ankles. Serum uric acid was $11.3 \mathrm{mg}$. and blood urea $112 \mathrm{mg}$. The congestive failure and a concurrent urinary infection responded to treatment with a low-salt diet and antibiotics, the blood urea falling to $60 \mathrm{mg}$. and the serum uric acid to $5.9 \mathrm{mg}$. without uricosuric therapy. In April 1959 treatment with colchicine and probenecid was started because the serum uric acid was $8.8 \mathrm{mg}$. There has been no further acute gouty arthritis.

\section{Case 5}

This was the only case in this series of hyperparathyroidism secondary to chronic primary renal disease where long-standing 
renal failure was probably a major factor in causing hyperuricaemia and gout.

A male Nigerian was admitted to Hammersmith Hospital in January 1961 at the age of 41 with shortness of breath, polyuria, polydipsia, and loss of weight for three months. There had been nocturia for as long as he could remember, but no other symptoms of previous renal or cardiac disease. On examination the blood-pressure was $170 / 120$ and the heart was enlarged, with no signs of congestive failure. The joints were normal and there were no tophi. The urine contained protein 0.4 to $2.5 \mathrm{~g}$. daily with occasional leucocytes on microscopy and was sterile on culture. Blood urea $170 \mathrm{mg}$./ $100 \mathrm{ml}$., calcium $3.4 \mathrm{mEq} / \mathrm{l}$., phosphate $3 \mathrm{mEq} / \mathrm{l}$., alkaline phosphatase $32 \mathrm{~K}$.-A. units. Plain $x$-ray films of the abdomen failed to define renal shadows; there were cortical erosions of hyperparathyroidism in the hands and feet, also in the pelvic bones and femoral trochanters. A diagnosis was made of either chronic pyelonephritis or glomerulonephritis with secondary hyperparathyroidism, and treatment was begun with a $40-\mathrm{g}$. protein diet and guanethidine, $20 \mathrm{mg}$. daily. In May he was readmitted in left ventricular failure and was digitalized. During that admission, and for the first time, he had two attacks of gout in the great toes, the serum uric acid being $12 \mathrm{mg}$. and blood urea $133 \mathrm{mg} . / 100 \mathrm{ml}$. He later returned to Nigeria, where he died; no post-mortem examination was carried out.

\section{Cases 6-12}

Case 6 was an example of primary hyperparathyroidism and nephrocalcinosis; she was found to have a raised serum uric acid but no gout, and her blood urea was normal. In Cases 7 to 11 there was hyperparathyroidism, nephrocalcinosis, and hyperuricaemia, but evidence of some degree of renal failure which may have contributed to uric-acid retention. These patients have not had clinical gout.

Case 7.-A woman aged 57, who in 1961 developed hallucinations and other mental disurbances, was admitted to Hammersmith Hospital because of the possibility of an organic psychosis. Examination revealed no abnormality apart from the mental state and a mild hypertension of $160 / 110$, but serum calcium was elevated at $7.7 \mathrm{mEq} / 1$., phosphate $1.2 \mathrm{mEq} / 1$., alkaline phosphatase $32 \mathrm{~K}$.-A.

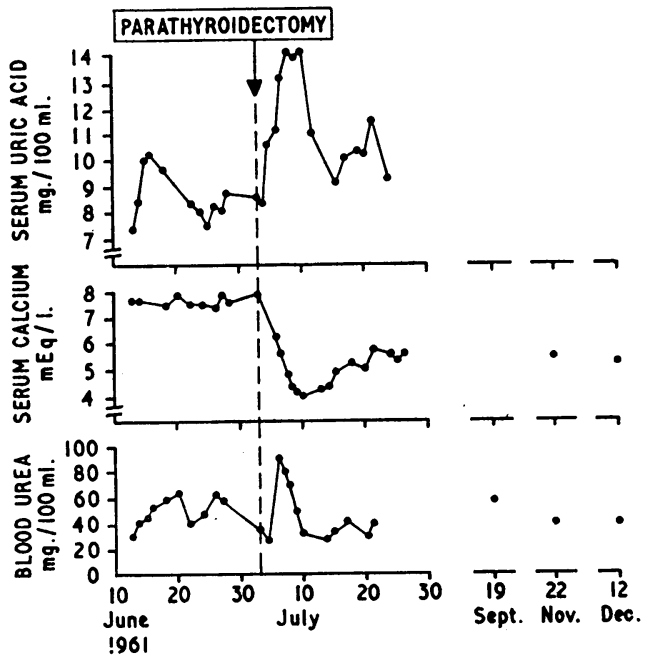

Fig. 4.-Pre- and post-operative course in Case 7.

units, blood urea ranging from 32 to $64 \mathrm{mg} . / 100 \mathrm{ml}$., and serum uric acid 7.4 to $10.2 \mathrm{mg}$. $X$-ray examination showed bilateral nephrocalcinosis. The diagnosis of hyperparathyroidism was supported by an abnormal phosphate-excretion index (Nordin and Fraser, 1960) and strontium-infusion test (Fraser et al., 1960), and by cortisone failing to produce a significant suppression of serum calcium. In July 1961 a parathyroid adenoma was removed by Professor Aird, the serum calcium falling to $4 \mathrm{mEq} / \mathrm{l}$. (Fig. 4) In the first six post-operative days the blood urea rose from 36 to $90 \mathrm{mg}$., then fell again to the former level, while the serum uric acid rose from 8.4 to $14.2 \mathrm{mg}$., similarly falling again. The final uric acid figure before discharge was $9.4 \mathrm{mg}$. and the blood urea has since lain between 42 and $60 \mathrm{mg}$. After the operation her mental condition improved.

In Case 12 many estimations of serum uric acid were normal before and after removal of a parathyroid adenoma despite a pre-operative serum calcium of $6.6 \mathrm{mEq} / 1$.

\section{Discussion}

Out of 12 patients in whom the serum uric acid was estimated, abnormally high values were obtained in 11 . Clinical gout occurred in five of these, and it is noteworthy that three of them were women and in two (Cases 1 and 2) gout occurred before the menopause, which in primary gout is extremely rare. The normal serum uric acid in Case 12 indicates that hyperuricaemia is not universal.

Most of the patients had impaired renal function as shown by a raised blood urea at some time in the course of the disease. This was already elevated pre-operatively in Cases $2,3,4,7,8$, 9,10 , and 11 , and a transient post-operative rise occurred as well in Case 6 . In these patients, therefore, there may well have been some diminution in the load of uric acid filtered at the glomeruli, contributing to the rise in serum uric acid. That this was so is strongly suggested in at least cases 3,4 , and 7 , where frequent estimation of blood urea and serum uric acid showed that these values tended to run parallel to each other, especially in a post-operative rise and fall. In Case 5, where secondary hyperparathyroidism was associated with chronic nephritis and uraemia, this was probably the main or sole cause of the hyperuricaemia.

Uraemia cannot, however, be accepted as a major factor in producing hyperuricaemia in most of these patients. In Case 1 hyperuricaemia and acute gouty arthritis occurred preoperatively in a young woman of 26 at a time when the blood urea was normal. In Case 2, while various tests showed some impairment of renal function pre-operatively, the blood urea was either normal or only slightly raised at this time, and it is difficult to believe that the first attack of gout six years previously was due to renal failure. Uraemia in the other hyperuricaemic patients was mostly mild and transient. It is indeed of interest that one patient (Case 8) went into a state of chronic uraemia with a blood-urea level usually about $150 \mathrm{mg}$., terminating in death two years later; but the serum uric acid, which was $6.6 \mathrm{mg}$. pre-operatively, remained below $6 \mathrm{mg}$. on the two occasions it was estimated in the two succeeding years. While renal failure may cause hyperuricaemia, it usually has to be of greater severity and duration than occurred in most of these patients, and gout due to uraemia is extremely rare.

A more likely explanation is the existence in hyperparathyroidism of a special type of renal lesion leading to hyperuricaemia and thence to gout. This lesion may be associated with calcium deposition in the kidney and would be situated in that part of the tubule associated with the active secretion of uric acid known to occur in the human kidney (Gutman et al., 1959). Of the five patients in this series with gout, three had nephrocalcinosis visible radiologically, and one of them had soft-tissue calcification elsewhere ; while of the total of 11 with hyperuricaemia six had radiological nephrocalcinosis and five soft-tissue calcification elsewhere. Hyperuricaemia and gout have also been noted in conditions with soft-tissue calcification other than hyperparathyroidism-as in the case with articular cartilage calcification and a normal serum calcium described by Harmon (1944) and the patient of Wallach et al. (1956) with so-called pseudo-pseudohypoparathyroidism, who had softtissue calcification about the joints, along muscle sheaths, and in the scalp. We have recently had under our care a patient with histologically confirmed sarcoidosis, hypercalcaemia, and soft-tissue calcification whose serum uric acid was $10.6 \mathrm{mg}$. while the serum calcium was elevated at $6.9 \mathrm{mEq} / 1$, and which fell to $4.6 \mathrm{mg}$. $/ 100 \mathrm{ml}$. as the calcium also fell to $5.1 \mathrm{mEq} / 1$. 
on corticosteroid treatment, the blood urea being $45 \mathrm{mg}$. and $31 \mathrm{mg} . / 100 \mathrm{ml}$. on the two occasions.

If this hypothesis is correct, it is probably actual calcium deposition in the tubule which impairs the excretion of uric acid rather than merely the inhibiting effect of a raised serum calcium. In the first place hyperuricaemia and gout have, as just noted, been observed where there is soft-tissue calcification in the absence of hypercalcaemia. Secondly, the acute experiment carried out on a healthy woman by Mintz et al. (1961), in which they raised the serum calcium with " parathormone," failed to demonstrate any significant fall in uric-acid clearance. These authors also reported that the serum-uric-acid levels in their patients with hyperparathyroidism and hyperuricaemia rose during the immediate post-operative period and then fell to their former levels, but not to normal. In normouricaemic patients the levels remained unchanged. The data in our patients are mostly inadequate to add to this, because of a lack of pre-operative serum-uric-acid estimation, because of renal failure, or because of treatment with uricosuric drugs. In Case 2 (Fig. 2) the serum-uric-acid level was $9.4 \mathrm{mg}$. three months after parathyroidectomy, a similar level to that before surgery. That the process may, however, be reversible is indicated by Case 1 (Fig. 1), where the range of serum-uric-acid readings fell from $5.7-10.8 \mathrm{mg}$. pre-operatively to $4.7-6.3 \mathrm{mg}$. after parathyroidectomy; as well as by the fall in serum uric acid seen in the above-mentioned patient with sarcoidosis.

Dubin et al. (1956) found hyperuricaemia and a diminished uric-acid clearance in 11 patients with hypoparathyroidism, mostly after thyroidectomy. Probenecid produced a fall in serum uric acid and a rise in urine uric acid, and these were paralleled by similar changes in serum and urine phosphate. It was suggested that the same mechanism responsible for hyperphosphataemia might account for hyperuricaemia. This could not apply to patients with hyperparathyroidism where there is no such relation between serum phosphate and uric acid (in Case 1 the serum levels were actually inversely related, phosphate rising post-operatively and uric acid falling). Sodium dihydrogen phosphate has been used to produce experimental nephritis in the rat by McFarlane (1941), who suggested that the segment of tubule involved was the site of acidification of urine in the rat. In Dunn and Polson's (1926) experiments, producing necrosis of segments of distal renal tubule by lithium urate, the localization of lesions appeared to be determined by precipitation of uric acid in these segments, and it was suggested that this precipitation occurred at the site where the urine became acid. It seems possible that in this region of the tubule, where there is loss of hydrogen ion, calcium is precipitated and uric-acid secretion is suppressed. Oliver (1949) found that deposition of calcium in the rat nephron after administration of calciferol or parathormone was mainly in the proximal convoluted tubule.

During a period of post-operative study in Case 2 it was shown that pyrazinamide and probenecid produced their usual anticipated effects on uric-acid excretion, the former depressing it and the latter enhancing it, with corresponding rise and fall in the serum levels. Prednisolone $30 \mathrm{mg}$. daily had no noticeable effect.

Mintz et al. (1961) found a family history of gout in two of their eight patients with hyperparathyroidism and discussed the possibility of a genetic influence in the combined abnormalities of gout and hyperparathyroidism rather than a direct physio- logical correlation between parathyroid function and uric-acid metabolism. None of our patients had a family history of gout, and, for the reasons given, a direct relation between calcification and uric-acid retention is postulated.

Another possibility to be considered is that the gout in these patients is not uric-acid gout but a calcium pseudogout of the type described by McCarty et al. (1962), where acute arthritis is produced by intra-articular deposition of calcium. Although this could be excluded only by biopsy and identification of crystals, the accompanying hyperuricaemia would then be an unrelated event, an unlikely coincidence.

Finally, while these findings support the suggestion of Mintz et al. that gouty patients, particularly those with renal stones, should be screened for hyperparathyroidism, we have failed to detect this condition in over 100 patients with gout attending Hammersmith Hospital over the past year, although one patient with recurrent renal stones did have essential hypercalciuria. Hyperparathyroidism must therefore be a rare cause of gout.

\section{Summary}

An account is given of 11 patients with both hyperparathyroidism and hyperuricaemia, five of whom had acute gouty arthritis, in two instances in premenopausal women. Most of the patients had impairment of glomerular function as indicated by a raised blood-urea level at some time in the course of the disease. This was thought to be no more than a contributory cause for the hyperuricaemia, and the existence is postulated of a renal tubular lesion secondary to calcium deposition. Six of the patients had nephrocalcinosis radiologically. Examples are given of hyperuricaemia and gout occurring in other conditions with soft-tissue calcification.

We are grateful to our colleagues for permission to study cases admitted under their care and in particular to Professor Russell Fraser and Dr. Oliver Wrong, at Hammersmith, and Dr. John Lister, at Taplow ; also to Dr. K. North and Dr. B. L. J. Treadwell for their work in the study.

\section{REFERENCES}

Bidmead, D. S. (1951). F. clin. Path., 4, 370.

Bywaters, E. G. L., Dixon, A. St. J., and Scott, J. T. (1963). Ann. rheum. Dis., 22, 171.

Caraway, W. T. (1955). Amer. F. clin. Path., 25, 840.

Dent, C. E. (1962). Brit. med. f., 2, 1419.

Downs, R. S., and Scott, V. (1941). Arch. intern. Med., 67, 658.

Dubin, A., Kushner, D. S., Bronsky, D., and Pascale, L. R. (1956) Metabolism, 5, 703.

Dunn, J. S., and Polson, C. J. (1926). F. Path. Bact., 29, 337.

Fraser, R., Harrison, M., and Ibbertson, K. (1960). Quart. F. Med., 29, 85.

Gordan, G. S., Eisenberg, E., Loken, H. F., Gardner, B., and Hayashida, T. (1962). Recent Progr. Hormone Res., 18, 306

Gutman, A. B., Yü, T. F., and Berger, L. (1959). $\dot{f}$. clin. Invest., 38 1778.

Harmon, P. H. (1944). f. Bone ft Surg., 26, 838.

Hosking, G. E., and Clennar, G. (1960). Ibid., 42B, 530.

McCarty, D. J., Kohn, N. N., and Faires, J. S. (1962). Ann. intern. Med., 56, 711 .

McFarlane, D. (1941). f. Path. Bact., 52, 17.

Mintz, D. H., Canary, J. J., Carreon, G., and Kyle, L. H. (1961). New Engl. ๆ. Med., 265, 112.

Nordin, B. E. C., and Fraser, R. (1960). Lancet, 1, 947.

Oliver, J. (1949). In Renal Function: Transactions of the First Conference, fosiah Macy fr. Foundation, New York, pp. 39, 40.

Popert, A. J., and Hewitt, J. V. (1962). Ann. rheum. Dis., 21, 154.

Wallach, S., Englert, E., and Brown, H. (1956). Arch. intern. Med., 98 517. 